
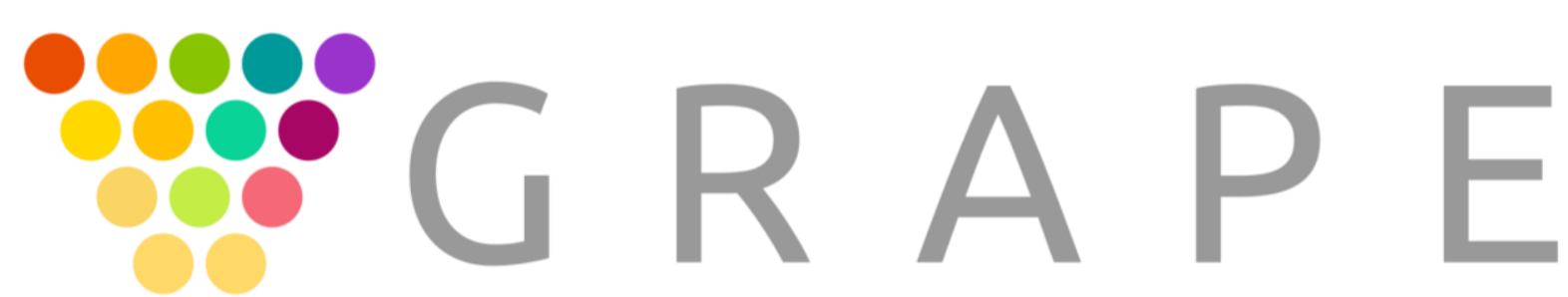

Group for Research in APplied Economics

GRAPE Working Paper \# 9

Cyclical trend of labor reallocation in Poland: transition and structural change

Stanisław Cichocki, Joanna Tyrowicz, Lucas van der Velde

Foundation of Admirers and Mavens of Economics

Group for Research in Applied Economics 


\title{
Cyclical trend of labor reallocation in Poland: transition and structural change
}

\author{
Staniław Cichocki \\ University of Warsaw
}

\author{
Joanna Tyrowicz \\ FAMEIGRAPE \\ University of Warsaw
}

\author{
Lucas van der Velde \\ FAME|GRAPE
}

\begin{abstract}
Using data from the Polish Labor Force Survey for 1995-2015 we construct measures of worker flows and inquire their cyclical properties as a way to test the predictions of structural change/transition theories regarding the reallocation process that took place in Eastern European and FSU countries. This process has two features: the decline in public sector employment combined with an increase in private sector employment and the reallocation of labor from manufacturing to service sector. We find that labor market adjustments tend to amplify in upturns of the business cycle, while worker flows contribute only a fraction to the changing structure of employment.
\end{abstract}

Keywords:

wage inequality, structural change, transition, skill biased technological change

JEL Classification

J21, J62, P31

Corresponding author

Stanisław Cichocki, scichocki@wne.uw.edu.pl

Acknowledgements

Authors would like to thank Karsten Staehr, Jan Rutkowski, Tomasz Mickiewicz, Jan Svejnar, Marcello Signorelli, Magdalena Smyk, Karolina Goraus, Wojciech Hardy and an anonymous referee for their insightful suggestions. The paper benefited greatly from the comments of the participants of WIEM (2015), AIEL conference (2015), Deutsche Gesellschaft für Osteuropakunde workshop (2016) and GRAPE seminars. This work was supported by the National Science Center under Grant UMO-2012/05/E/HS4/01506

Published by: $\quad$ FAME | GRAPE

ISSN:

$$
\text { 2544-2473 }
$$

(c) with the authors, 2017 


\section{Introduction}

In the early 1990s, following theoretical insights, as well as common sense, economists postulated that Eastern European and Former Soviet Union (FSU) countries would undergo a massive labor force reallocation. Transition economists argued that the (inefficient) state owned enterprises will have to reduce its personnel, yielding substantial flows of workers to the (emerging) private sector. In addition, there could also be a flow of jobs, if part of the transition happened via privatizations rather than bankruptcies. The theoretical foundation for these adjustments was laid by Aghion and Blanchard (1994), with subsequent extensions. Indeed, in most transition economies public sector share in employment is currently less than half of what it used to be 25 years ago. However, unlike expected, it appears that only a small fraction of this reallocation of labor force occurred via privatizations or actual flows of workers from employment to employment, with or without a period of unemployment or inactivity. What was driving the reallocation process was elderly labor market exit to retirement and youth labor market entry from education.

In addition to the ownership structure, at the beginning of transition, most labor and development economists emphasized that many of these economies were too industrialized, i.e. their service sector was to small, relative to other countries with a similar development level. Then, transformation could be considered similar to an adverse shock in tradable goods triggering reallocation from manufacturing to services, following the premises of Caballero and Hammour (1996a, 1996b, 1998, 2000). Indeed, especially Central and Eastern European countries (CEECs) experienced a decline in manufacturing and an increase in service share in both employment and output. In contrast to theory, however, flows between sectors - direct or with interim unemployment - contributed only marginally to the change in the sector composition of employment.

The empirical evidence, somewhat in contradiction to the theoretical predictions, constitutes a puzzle. The objective of this paper is then twofold. First, we document the puzzle using 20 years of labor market flows in a large transition economy, Poland. We analyze explicit worker gross and net flows across sectors and forms of ownership and show the contribution to the changing employment structure coming from labor reallocation and demographic processes (entry of young cohorts and exit of older cohorts). We quantify the contribution of flows posited by Aghion and Blanchard (1994) model as well as Caballero and Hammour (1996a, 1996b, 1998, 2000) models. To that end we analyze the descriptive statistics of our sample. We also describe the flows over the research period using graphs. 
Second, we analyze the trend and cyclical patterns of these flows to test if the adjustments exhibited more cyclical or more trend properties. Namely, if one considers transition to be a structural shift, it should exhibit at low frequencies in time series of labor market flows lower than the business cycle. However, as argued by Jaimovich and Siu (2012), some of the structural adjustments may occur asymmetrically strongly during economic slowdown. Thus, our cyclical decomposition of these time series recovered from the micro-level data permits identifying the dynamics of the economic transition in the labor markets. To that end we apply Hodrick-Prescott filtering to the time series of quarterly worker flows. To address the point raised in earlier studies that some of the reallocation processes gain momentum, while others fade out, we also split the sample in four equal intervals and thus test for the time stability of the estimates for each of the sub-periods separately.

Our paper is clearly not the first one on the topic, but it offers two novelties relative to the earlier literature. First, we observe gross worker flows (in addition to net changes in employment structure) utilizing quasi-panel dimension of the Polish Labor Force Survey (LFS). Indeed, the gross flows are the ones which found most theoretical insights (Blanchard and Diamond, 1992; Davis, Faberman and Haltiwanger, 2005; Shimer, 2007) ${ }^{1}$. In the case of CEECs and Former Soviet Union countries, the literature on labor flows in the context of labor reallocation was largely constrained by data availability, thus often relying on net flows data. Observing quarterly flows for each individual over the 6 quarters (s)he was present in the sample we may calculate actual gross worker flows.

The second novelty lies in the nature of data used: 20 years of quarterly Labor Force Survey (LFS). Earlier studies for CEECs and FSU countries investigated usually shorter time spans, which implies selective coverage. For example, Konings et al. (1996); Haltiwanger and Vodopivec (2002); Brown and Earle (2002, 2006); De Loecker and Konings (2006) analyse early transition (various sub-periods between 1991 and 1998). By contrast, Sibertova and Senaj (2007); Gimpelson et al. (2010) analyze late transition (post 2001). Shorter time spans make cyclicality analyses impossible. ${ }^{2}$ Thanks to 80 quarterly observations, we may employ

\footnotetext{
${ }^{1}$ The inflows and outflows from one category to another are often very significant in numbers and more informative than the static size of labor market categories as the former deliver information on changes in a given category. Therefore a vast number of analyses focusing on labor market flows has been written over the last years (i.e. Elsby, Michaels and Solon, 2007; Petrongolo and Pissaridies, 2008; Nagypal, 2008; Elsby, Hobijn and Sahin, 2008; Gomes, 2010; Davis, Faberman and Haltiwanger, 2011; Davis and Haltiwanger, 2014).

${ }^{2}$ The longest period which is being analysed in the literature on labor reallocation in Eastern European and Former Soviet Union countries is 1992-2001 (Maaso and Heshmati, 2004).
} 
filtering characteristic of business cycle analyses and test explicitly if the correlation with the business cycle has changed over the analyzed period.

Our results reveal that the cyclical properties of the gross worker flows tend to be fairly stable over the two decades of the transition period. Moreover, we show that flows themselves are not procyclical, but the long term tendencies tend to amplify during periods of business cycle upturns. This finding suggests that the role of labor market frictions has been substantial on both demand and supply side, and temporary unemployment was much rarer than permanent inactivity, even in the case of Poland, the country with the highest unemployment rate in the region.

The paper is structured as follows. Section 2 reviews the relevant literature. Section 3 presents the data and describes the labor flows related to reallocation. Their time trends are presented in Section 4 and the behavior of the flows over the business cycle is discussed in Section 5. In the last section, we provide the conclusions from our study.

\section{Literature review}

The labor economics literature posits two distinct processes to describe labor reallocation in CEECs and Former Soviet Union countries. The first one was the closure of inefficient state owned enterprises and a decline of employment in the public sector combined with the emergence of an (allegedly) efficient private sector. In this case, job flows may come in two different forms: privatization, when workers stay in the firm, but the ownership structure changes to private; or worker flows between different jobs in different companies, possibly with a spell of unemployment between them.

The theoretical background for this transformation is provided by the highly influential model of Aghion and Blanchard (1994; henceforth AB). In this framework, a (possibly transitory) non-employment spell usually happens with state support; while, at the same time, the collapse of the public sector limits the options to raise the funds necessary to intensify social safety nets expenditure. The state raises funds to finance safety nets by taxing labor, which pushes up the (non-wage) cost of labor. If the fiscal gap grows too fast (i.e. taxes are levied too high), job creation lags behind job destruction. The accumulating non-employment pushes wage claims down, but the tax wedge prevents robust job creation, deepening the social costs of public-to-private sector reallocation. ${ }^{3}$ If speed of job destruction is

\footnotetext{
${ }^{3}$ Clearly, both the 'non-employment' and the 'taxes' should be taken figuratively, not literately. Benefits may comprise also pre-retirement benefits made available to individuals aged between 40 and retirement age to
} 
synchronized with the capacity of the emerging private sector to create new jobs, the nonemployment pool is low, fiscal needs small, levied taxes are less distortionary, and the economy may find itself on a fairly efficient equilibrium. Otherwise, an unstable high nonemployment equilibrium emerges.

The second type of a process concerns sectoral allocation of workers: declining manufacturing and increasing service sector. With non-controversial assumptions of contract incompleteness and capital specificity ${ }^{4}$, this reallocation has been conceptualized by Caballero and Hammour (1996a, 1996b, 1998, 2000; henceforth $\mathrm{CH}$ ). In the model, capital specificity generates quasi-rents (a surplus over the value of the match) which can be partially appropriated by workers despite being firm-specific thanks to contract incompleteness. Given the adjustment costs, impulse to reallocate labor may hence yield excessive job destruction and insufficient job creation. With one sector in a model, such shock desynchronizes job creation and destruction. With heterogeneous sectors, quasi-rents imply sudden increases in non-employment and slow job creation. In the limit, employers create little or no jobs at all, despite increasing demand for the final product.

The empirical literature on this topic is abundant and diverse. The analyses typically focus on jobs flows (job creation and destruction) and/or workers flows (hirings and separations) using either LFS or firm level data obtained in various ways i.e. gathered by national administrations, from Amadeus database or from dedicated surveys, among others. This diversity difficults a direct comparison of the results of these studies, but some tentative conclusions might be drawn. First, authors usually demonstrate high job destruction in manufacturing and state owned enterprises (SOEs) along with vivid job creation in the private sector (e.g. Konings, Lehmann and Schaffer, 1996; Bilsen and Konings, 1998; Haltiwanger and Vodopivec, 2002; De Loecker and Konings, 2006). However, when pulled together from all the available studies, estimates of the flows tell a different story. Utilizing empirical evidence from 18 different studies, Svejnar et al. (2016) show that the average reported destruction rates in the SOEs are not statistically larger than in the emerging private sector. By contrast, job creation rates are lower in SOEs and manufacturing. This pattern was suggested by De Loecker and Konings (2006) for Slovenia, but appears to be fairly general.

discourage them from participating in the labor market, as has been frequently done. Also taxes should be viewed in a broad sense as they may encompass the opportunity costs of expanding productivity enhancing infrastructure instead of benefits.

${ }^{4}$ Capital is specific to a given relation in the sense that if the relation is broken a part of the capital is lost. Training of employees is an example of capital-specificity. 
Second, most of the early studies argue that job destruction and job creation alike only gradually gained momentum. In some cases this process is believed to intensify over time (e.g. see Brown and Earle, 2003 for Russia). Haltiwanger and Vodopivec (2002), using the example of Estonia, explain this by the massiveness of the processes: job destruction and separations took place mostly in large, state-owned enterprises in manufacturing, which were often "supported" by public subsidies at least over some initial period. In a similar vein, small private firms in the service sector exhibited high job creation and hirings, but before the scale of these processes had grown, time was needed for these enterprises to expand. However, as suggested by the overview of a large share of the literature in Svejnar et al. (2016), this time pattern was not uniform across all analyzed countries. One of the potential reasons behind the dispersion in time trends may stem from low synchronization of the business cycles between those economies (e.g. due to different initial structure of production, asymmetric external shocks as well as different macroeconomic and privatization policies).

Finally, driven by theoretical insights, majority of research has focused on between sectors flows (of workers or jobs). Meanwhile, there is important evidence that those between flows may not have been the most important driver of the change in the structure of employment. First, as suggested by Haltiwanger and Vodopivec (2002), within sector reallocation of workers has been fairly large in Estonia and Slovenia. Using firm level data, Faggio and Konings (2003) argue that most of the worker flows occur within sector also in Romania and Bulgaria (presumably from less efficient to more efficient firms). In addition to the within flows, youth inflows and elderly outflows also played a role. As much as two decades earlier, roughly half of the currently working population has not worked prior to the transition, while a roughly equal number of workers has left the labor market to retirement. The flows due to demographic processes are clearly large enough to trump any effect of between jobs reallocation of workers - mediated by unemployment spells or not.

Summarizing, it appears that, after over two decades of research, not all of the initial theoretical prerequisites stand against the empirical evidence. Job creation may be more relevant than job destruction for explaining the dynamics of employment stocks. Moreover, the processes of labor market reallocation may have been driven by business cycle and demographics rather than by transition in terms of employment structure.

Our paper complements this earlier literature in four respects. First, we employ worker level data and analyze the gross worker flows in one of the largest transition economies, Poland. While this is not the first study to work with individual flows, we add the demographic dimension to the data, i.e. we incorporate labor market entries (of the youth) and 
exits (of the older workers) into the picture. Second, exploiting the advantage of long time coverage, we analyze the cyclical patterns of over two decades of labor market flows. Our data is a decade longer than the longest period previously analyzed. Such long time span allows for employing time series techniques to filter the cyclical component of the flows from the trend component of the flows. Third, our data is of quarterly nature, which is particularly useful for analyzing labor market flows. In fact, with yearly data flows are underestimated, which is less likely to be the case with the quarterly data. ${ }^{5}$ Finally, while similar to some earlier studies, we only cover one country, we hope to contribute by analyzing the role of fairly general phenomena: demographic transition and fluctuations in economic activity due to business cycles.

\section{Data}

We use quarterly data from the Polish Labor Force Survey (LFS). Data spans from the first quarter of 1995 to $2015 .{ }^{6}$ These are individual level data, which permit tracing labor market trajectories and aggregate them to gross worker flows. The sample design standard for LFS encompasses a period of 6 quarters for each individual, with a 2-2-2 design which means that the individual is observed for two quarters, then there is a break of two quarters and after the break the individual is once again observed for two quarters. This implies 4 quarterly observations for each individual.

The database is rich in individual and firm characteristics. Survey comprises question about the form of ownership as well as NACE codes of the employer. Thus, we may identify public dummy for each worker and trace changes in this dummy over time. We may also identify manufacturing and service sectors (as well as exclude agriculture and construction from the analyses). Finally, as is standard in LFS, the survey includes information on personal characteristics of the workers, such as education, along with different labor market status, unemployment, retirement as well as employment.

Based on the available information we identify a set of theory-motivated labor market trajectories. First, we distinguish a change of employer's ownership form: if employer status changed from public to private, as in Aghion and Blanchard (1994) model, we identify such

\footnotetext{
${ }^{5}$ E.g.. a person can be unemployed, take up employment and be fired during the course of a year which corresponds to two flows (one from unemployment to employment and one from employment to unemployment) but neither of them will be captured when using yearly data.

${ }^{6}$ The first LFS was conducted in Poland in May 1992; however, the sample design as well as definitions conform with ILO standards as of 1995 onwards.
} 
worker flow as PubPriv. If sector of employment changed from manufacturing to services, we identify such worker flow as ManSer (in line with Caballero and Hammour, 1998). Worker flows which involve a change of both ownership (from public to private) and sector (from manufacturing to services) are coded as PubPrivManSer. Both measures comprise cases with interim unemployment or non-employment. We also distinguish youth labor market entry from education and elderly labor market exit to retirement. In a similar spirit we code inflows and outflows to manufacturing, services as well as public and private sectors. Each of the flows has its complement.

\section{Table 1. Descriptive statistics in the sample}

\begin{tabular}{l|r|r|r} 
Variable & All years & $1995-2005$ & 2005-2015 \\
\hline Wage employed & $33.7 \%$ & $34.8 \%$ & $33.0 \%$ \\
\hline Unemployed & $6.3 \%$ & $8.3 \%$ & $4.9 \%$ \\
\hline Inactive & $48.6 \%$ & $43.3 \%$ & $52.2 \%$ \\
\hline Working in manufacturing & $10.8 \%$ & $11.8 \%$ & $10.0 \%$ \\
\hline - entering in observation window & $1.5 \%$ & $1.8 \%$ & $1.1 \%$ \\
\hline - exiting in observation window & $3.7 \%$ & $4.3 \%$ & $3.0 \%$ \\
\hline Working in services & $13.8 \%$ & $13.1 \%$ & $14.3 \%$ \\
\hline - entering in observation window & $1.6 \%$ & $2.2 \%$ & $1.2 \%$ \\
\hline - exiting in observation window & $4.0 \%$ & $4.7 \%$ & $3.4 \%$ \\
\hline Working in public sector & $14.8 \%$ & $19.5 \%$ & $11.4 \%$ \\
\hline - entering in observation window & $1.8 \%$ & $1.4 \%$ & $2.4 \%$ \\
\hline - exiting in observation window & $4.4 \%$ & $4.1 \%$ & $5.0 \%$ \\
\hline Working in the private sector & $19.0 \%$ & $15.3 \%$ & $21.6 \%$ \\
\hline - entering in observation window & $3.7 \%$ & $5.4 \%$ & $2.8 \%$ \\
\hline - exiting in observation window & $1.5 \%$ & $1.9 \%$ & $1.3 \%$ \\
\hline ManSer & $0.7 \%$ & $0.7 \%$ & $0.6 \%$ \\
\hline PubPriv & $2.5 \%$ & $2.0 \%$ & $3.1 \%$ \\
\hline PubPrivManSer & $0.1 \%$ & $0.1 \%$ & $0.1 \%$ \\
\hline Youth entrant & $0.4 \%$ & $0.3 \%$ & $0.4 \%$ \\
\hline Elderly exit & $0.1 \%$ & $0.1 \%$ & $0.1 \%$ \\
\hline No of observations & 4839546 & 1781121 & 3058425
\end{tabular}

Note: Polish LFS, 1995q1-2015q1, shares in total population, flows relative to the relevant population, youth entrants and elderly leavers relative to total population. To compute flows, population weights were utilized.

Table 1 reports descriptive statistics for our sample. In total, our sample comprises over 4 million individuals, with roughly $62 \%$ of the sample observed 4 times. We drop approximately 265 thousand observations (or $5.6 \%$ of the sample) because these individuals were observed only once due to the attrition of the panel, which seems to be a natural consequences of the LFS as data is collected through face-to-face interviews. For illustrative purposes the available sample was split in half, which also reveals that the more recent waves 
of LFS were more numerous than the initial ones. Like in other countries, public sector employment declined substantially in Poland - partly due to worker flows and partly due to job flows. Meanwhile, the manufacturing share in employment has remained fairly stable, while the increase in private sector has been as high as $30 \%$. However, the figures in Table 1 report averages over a decade, masking substantial changes in stocks and flows over the shorter horizons. Thus, in the reminder of this paper we reduce the dimensionality of this study to quarterly frequency and focus on the time dimension. We utilize the individual data to compute quarterly flows and analyze their properties.

\section{Time trends in labor market flows}

Consistent with $\mathrm{AB}$ theory, public sector employment decreased by roughly $50 \%$ between 1995 and 2015: from about 7.3 million people to 3.9 million people. Clearly, the whole transition period is associated with intensive outflows (Figure 1). However, the main bulk of the decline occurred between 1998 and 2002, which was the period of job flows rather than worker flows (i.e. privatization of the largest state owned enterprises took place, three of the largest privatized companies alone constituted app. 500 thousand employees). However, quarterly inflows to the public sector were on average as much as 80-150 thousand people (about $0.8 \%-1.5 \%$ of the labor force). It appears that outflows were in excess of inflows more strongly at periods of recessions.

Following the expectations and insights from $\mathrm{CH}$ theory, the service sector increased in terms of employment - by almost 60\% between 1995 and 2015 (from about 3.5 million people to about 5.5 million). However, in manufacturing, employment decreased marginally between 1995 to 2015, from about 3.8 million people to about 3.5 million people. Moreover, the dynamics are no longer consistent with the predictions of $\mathrm{CH}$ theories. First, inflows to manufacturing are substantial in absolute terms - roughly 100 thousand people per quarter (about $1 \%$ of the labor force). Moreover, one would have a weak case arguing that the intensity of these flows exhibits a clear time pattern. Flows tend to be larger - and more positive in net terms - at business cycle booms, but this tendency does not hold for each episode of the upturn.

Moreover, relative to the flows driven by demographics, flows driven by hirings or separations seem relatively small (Figure 2). In fact, ManSer type flows were of negligible magnitudes of roughly 10 thousand workers (about $0.1 \%$ of the labor force) per quarter and a comparable size of the opposite flows: from services to manufacturing, especially in early 
transition. The PubPriv flows were somewhat larger, with approximately 50 thousand workers per quarter (about $0.5 \%$ of the labor force). However, the opposite flows amounted to as much as 40 thousand workers ( $0.4 \%$ of the labor force) per quarter. Against the net figure for these flows of roughly minus 11 thousand workers, quarterly permanent labor market exits by the elderly were on average in excess of 30 thousand workers $(0.3 \%$ of the labor force). In addition, quarterly youth inflows surpassed on average 62 thousand workers $(0.6 \%$ of the labor force), which implies that the demographic change alone could yield a reallocation of as many as 30 thousand jobs between public and private sector in net terms, whereas worker flows fall short of a third of that.

Figure 1. Gross worker flows and net changes
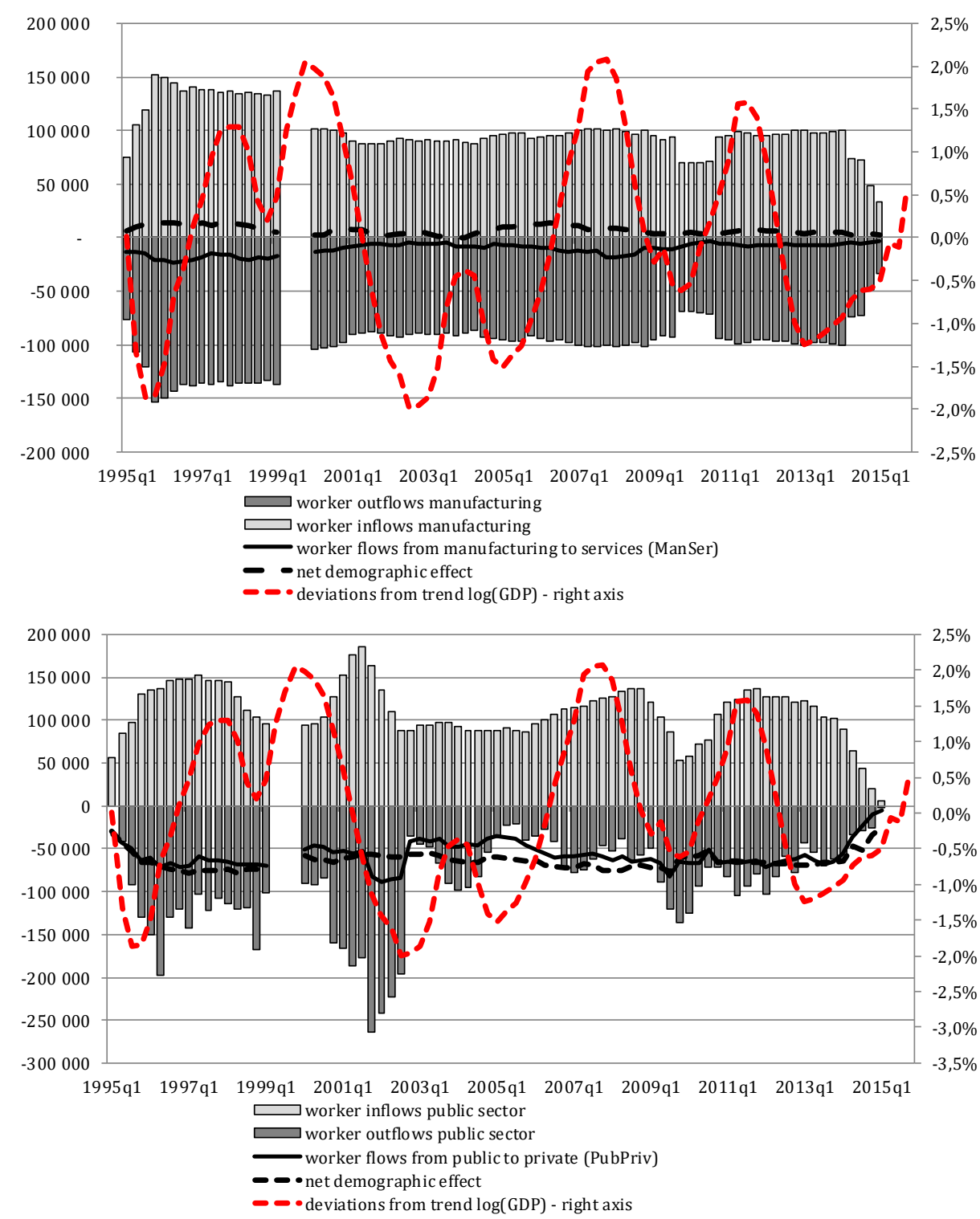

Note: Polish LFS, 1995q1-2015q1, deviations from trend (log) GDP from Hodrick-Prescott filtering with $\lambda=1600$, flows seasonally adjusted with TRAMO/Seats. 
Higher churning at booms and lower at busts resembles patterns observed for advanced economies (Davis, Faberman and Haltiwanger, 2011; Davis and Haltiwanger, 2014). However, this pattern is not universal. Data reveal a persistent but gradual decrease in the public and similarly persistent (even if more cyclical) increase in service sector employment. We move to analysing the cyclical properties.

Figure 2. Structural change and demographics

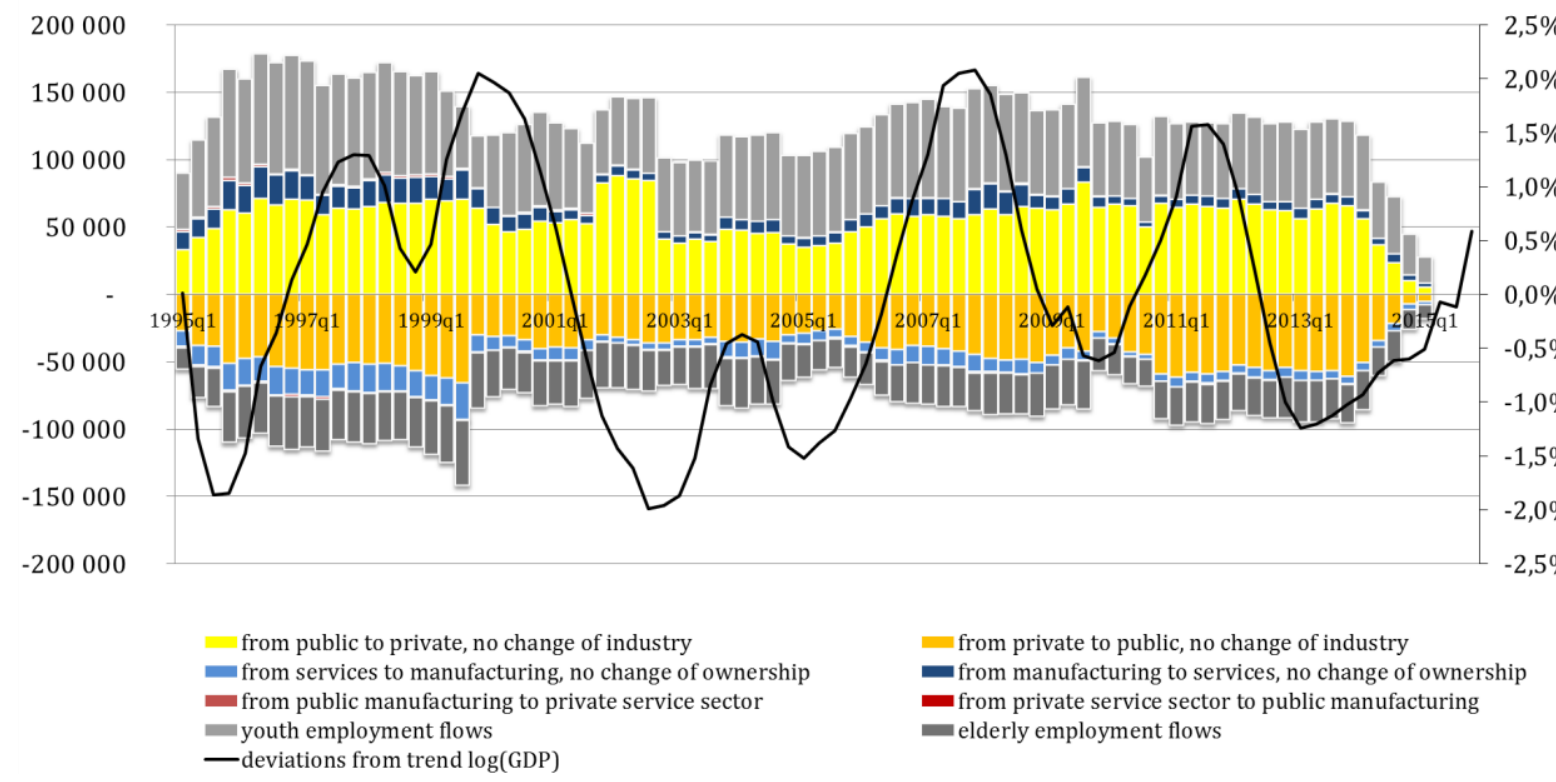

Note: Polish LFS, 1995q1-2015q1, deviations from trend (log) GDP from Hodrick-Prescott filtering with $\lambda=1600$, flows seasonally adjusted with TRAMO/Seats. Yellow signifies PubPriv and counter-PubPriv flows (change from public to private and vice versa), blue signifies ManSer and counter-ManSer flows (change in sector of employment from manufacturing to services and vice versa), red stands for PubPrivManSer and counter-PubPrivManSer and involves both types of changes in a given flow.

\section{Cyclical patterns}

To analyze the cyclical patterns of labor market flows we apply Hodrick-Prescott filtering to the time series of quarterly worker flows. ${ }^{7}$ The cyclical component is expressed in percentage deviation from long term trend. To address the point raised in earlier studies that some of the reallocation processes gain momentum, while others fade out, we also split the sample in four equal intervals and thus test for the time stability of the estimates for each of the sub-periods separately.

\footnotetext{
${ }^{7}$ Hodrick and Prescott (1997); Ravn and Uhlig (2002).
} 
Table 2. Cyclical patterns of labor market flows

\begin{tabular}{|c|c|c|c|c|c|c|c|c|}
\hline \multirow[b]{2}{*}{ VARIABLES } & \multicolumn{2}{|c|}{ PubPriv } & \multicolumn{2}{|c|}{ ManSer } & \multicolumn{2}{|c|}{ Exits from manufacturing } & \multicolumn{2}{|c|}{ Exits from public sect. } \\
\hline & $\begin{array}{c}\text { cycle } \\
(1) \\
\end{array}$ & $\begin{array}{c}\text { trend } \\
(2) \\
\end{array}$ & $\begin{array}{c}\text { cycle } \\
(3) \\
\end{array}$ & $\begin{array}{c}\text { trend } \\
(4) \\
\end{array}$ & $\begin{array}{c}\text { cycle } \\
(5) \\
\end{array}$ & $\begin{array}{c}\text { trend } \\
(6) \\
\end{array}$ & $\begin{array}{c}\text { cycle } \\
(7) \\
\end{array}$ & $\begin{array}{c}\text { trend } \\
(8) \\
\end{array}$ \\
\hline GDP cycle & $\begin{array}{c}1.38 \\
(5.83)\end{array}$ & $\begin{array}{l}\text { 47.14* } \\
(31.92)\end{array}$ & $\begin{array}{c}11.09 * \\
(7.36)\end{array}$ & $\begin{array}{c}23.72 * * * \\
(11.50)\end{array}$ & $\begin{array}{c}11.24 * * \\
(5.05)\end{array}$ & $\begin{array}{c}12.59 * \\
(8.38)\end{array}$ & $\begin{array}{c}0.66 \\
(4.93)\end{array}$ & $\begin{array}{c}\text { 86.52*** } \\
(38.24)\end{array}$ \\
\hline GDP trend & $\begin{array}{c}0.26 \\
(1.18)\end{array}$ & $\begin{array}{c}22.42 * * * \\
\quad(9.52)\end{array}$ & $\begin{array}{l}-0.10 \\
(1.49)\end{array}$ & $\begin{array}{c}-15.23 * * * \\
(3.43)\end{array}$ & $\begin{array}{c}0.36 \\
(1.02)\end{array}$ & $\begin{array}{c}-0.37 \\
(2.50)\end{array}$ & $\begin{array}{l}-0.62 \\
(1.00)\end{array}$ & $\begin{array}{c}7.80 \\
(11.41)\end{array}$ \\
\hline Interaction with period dumr & & & & & & & & \\
\hline 2000-2005 & $\begin{array}{c}4.46 \\
(6.52)\end{array}$ & $\begin{array}{c}-0.13 * \\
(0.09)\end{array}$ & $\begin{array}{c}5.67 \\
(8.23)\end{array}$ & $\begin{array}{c}-0.07 * * \\
(0.03)\end{array}$ & $\begin{array}{c}2.99 \\
(5.65)\end{array}$ & $\begin{array}{c}-\mathbf{0 . 0 3} * \\
(\mathbf{0 . 0 2})\end{array}$ & $\begin{array}{c}0.81 \\
(5.52)\end{array}$ & $\begin{array}{l}-0.09 \\
(0.10)\end{array}$ \\
\hline $2005-2010$ & $\begin{array}{l}-1.05 \\
(8.06)\end{array}$ & $\begin{array}{l}-0.12 \\
(0.12)\end{array}$ & $\begin{array}{c}2.54 \\
(10.16)\end{array}$ & $\begin{array}{c}-0.00 \\
(0.04)\end{array}$ & $\begin{array}{l}-6.21 \\
(6.98)\end{array}$ & $\begin{array}{c}-0.07 * * * \\
(0.03)\end{array}$ & $\begin{array}{c}1.60 \\
(6.81)\end{array}$ & $\begin{array}{l}-0.09 \\
(0.14)\end{array}$ \\
\hline $2010-2015$ & $\begin{array}{c}3.65 \\
(10.06)\end{array}$ & $\begin{array}{c}-0.12 \\
(0.15)\end{array}$ & $\begin{array}{l}-16.80 \\
(12.69)\end{array}$ & $\begin{array}{c}-0.04 \\
(0.05)\end{array}$ & $\begin{array}{c}-12.00 \\
(8.71)\end{array}$ & $\begin{array}{c}-0.07 * * \\
(0.04)\end{array}$ & $\begin{array}{l}-0.17 \\
(8.51)\end{array}$ & $\begin{array}{c}-0.05 \\
(0.18)\end{array}$ \\
\hline Service employment & $\begin{array}{c}5.93 \\
(5.04)\end{array}$ & $\begin{array}{c}-7.62 \\
(44.14)\end{array}$ & $\begin{array}{c}-10.58 \\
(6.36)\end{array}$ & $\begin{array}{c}-3.09 \\
(15.91)\end{array}$ & $\begin{array}{c}-3.47 \\
(4.36)\end{array}$ & $\begin{array}{c}3.56 \\
(11.59)\end{array}$ & $\begin{array}{l}-3.78 \\
(4.26)\end{array}$ & $\begin{array}{c}-9.63 \\
(52.88)\end{array}$ \\
\hline Manufacturing employment & $\begin{array}{l}-6.89 \\
(4.91)\end{array}$ & $\begin{array}{c}6.41 \\
(42.71)\end{array}$ & $\begin{array}{l}10.00 \\
(6.19)\end{array}$ & $\begin{array}{c}4.93 \\
(15.39)\end{array}$ & $\begin{array}{c}2.93 \\
(4.25)\end{array}$ & $\begin{array}{c}-3.46 \\
(11.21)\end{array}$ & $\begin{array}{c}3.14 \\
(4.15)\end{array}$ & $\begin{array}{c}6.72 \\
(51.17)\end{array}$ \\
\hline Private employment & $\begin{array}{c}0.73 * * * \\
(0.21)\end{array}$ & $\begin{array}{l}2.76 * \\
(1.54)\end{array}$ & $\begin{array}{c}0.26 \\
(0.27)\end{array}$ & $\begin{array}{c}0.48 \\
(0.55)\end{array}$ & $\begin{array}{c}0.03 \\
(0.18)\end{array}$ & $\begin{array}{c}0.49 \\
(0.40)\end{array}$ & $\begin{array}{c}0.21 \\
(0.18)\end{array}$ & $\begin{array}{c}5.98 * * * \\
(1.84)\end{array}$ \\
\hline Public employment & $\begin{array}{l}1.21 * \\
(0.65)\end{array}$ & $\begin{array}{c}1.36 \\
(5.04) \\
\end{array}$ & $\begin{array}{c}1.16 \\
(0.82) \\
\end{array}$ & $\begin{array}{l}-1.69 \\
(1.82)\end{array}$ & $\begin{array}{c}1.67 * * * \\
(0.56)\end{array}$ & $\begin{array}{c}0.45 \\
(1.32) \\
\end{array}$ & $\begin{array}{c}1.90 * * * \\
(0.55)\end{array}$ & $\begin{array}{c}4.82 \\
(6.04)\end{array}$ \\
\hline $\begin{array}{l}\text { Constant } \\
\text { Year FE }\end{array}$ & $\begin{array}{c}-3.10 \\
(14.50) \\
\text { Yes }\end{array}$ & $\begin{array}{c}-219.50^{*} \\
(116.79) \\
\text { Yes }\end{array}$ & $\begin{array}{c}1.45 \\
(18.30) \\
\text { Yes }\end{array}$ & $\begin{array}{c}206.28 * * * \\
(42.09) \\
\text { Yes }\end{array}$ & $\begin{array}{c}-4.19 \\
(12.56) \\
\text { Yes }\end{array}$ & $\begin{array}{c}14.87 \\
(30.66) \\
\text { Yes }\end{array}$ & $\begin{array}{c}7.66 \\
(12.26) \\
\text { Yes }\end{array}$ & $\begin{array}{c}16.51 \\
(139.91) \\
\text { Yes }\end{array}$ \\
\hline No of observations & 78 & 78 & 78 & 78 & 78 & 78 & 78 & 78 \\
\hline R-squared & 0.73 & 0.98 & 0.81 & 0.98 & 0.86 & 0.99 & 0.88 & 0.99 \\
\hline
\end{tabular}

Note: Polish LFS, 1995q1-2015q1, cyclical component measure is a deviation from trend, following Hodrick-Prescott filtering with $\lambda=1600$, standard errors reported in parentheses. $* * *$ denote significance at $5 \%$ level, $* *$ at $10 \%$ and $*$ at $15 \%$. Unless stated otherwise, RHS variables are trend components in trend regressions and cycle components in cycle regressions for LHS. Period 1995-2000 as base level. 
Estimates reveal that PubPriv flows are not cyclical and they respond positively to increased demand in the private sector as well as increased demand in public sector. Thus, it appears that these flows are, to a large extent, more an effect of churning than actual reallocation. The trend in PubPriv flows tends to amplify with business cycle booms. By contrast, ManSer cycles are strongly cyclical, although their trend tends to amplify with good business prospects. Hence, it appears that the time patterns associated with flows do emphasize the trend nature of the adjustments. As hinted by Caballero and Hammour (1996), in the periods of high economic activity, the flows tend to intensify, but this feature is general, unrelated to theories of transition.

Exits from manufacturing and exits from public sector (both to retirement or observationally permanent inactivity at older age) reveal why such patterns exist. First, both types of demographic exits are strongly pro-cyclical - periods of strong economic performance (and high job creation) tend to be associated with more intensive exits to retirement. ${ }^{8}$ This process weakens over time for exits from manufacturing, but not for exits from the public sector. In fact, public sector exits exhibit no business cycle properties, which suggests that whatever restructuring of labor force took place in manufacturing firms, it was post privatization. This finding would be consistent with the nature of many privatization agreements between the state and the buyer, which allowed only consensual downsizing. Firms utilized instruments such as voluntary early retirement exits to reduce head count and adjust worker skill structure.

\section{Conclusions}

Labor reallocation has been an immanent feature of transformation processes in Central and Eastern Europe as well as Former Soviet Union countries. Theory suggested that key components of these processes would be worker flows from public sector manufacturing to private sector services. Indeed, from the macroeconomic perspective, public sector has declined and (mostly private) service sector grew in importance in nearly every transition economy. However, empirical evidence from early years of transition has demonstrated that the reallocation paths are more nuanced than that. Adding to this literature, we present gross worker flows over two decades and analyze the business cycle properties of these flows.

\footnotetext{
${ }^{8}$ For brevity we do not report labor market entries by the youth, but they too are strongly pro-cyclical, which hints that generational exchange is associated with higher investment activity by firms.
} 
It appears that worker flows between jobs were relatively rare and followed the typical frictional labor market dynamics. The distinct forces that helped changing fundamentally the employment structure in the transformation economies were entry of young and exit of older workers. Moreover, the downsizing of the public sector - worker and job flows to private sector and elderly worker exits - exhibit no cyclical patterns, if anything, trends amplify at times of prosperity. While this is a structural change and thus one would expect a permanent trend rather than cyclical fluctuations, the fact that trend in these flows is strongly correlated with the business cycle hints that the trend may "be in the cycle", as recently argued for some types of jobs in the United States by Jaimovich and Siu (2012). Similar conclusions are drawn for the manufacturing sector.

Our findings provide an important policy guidance. First, despite the profound structural change ushered by abandoning the centrally planned system and introducing a market based one - the adjustments in employment seem to be typical for frictional labor markets. The bulk of net employment adjustment occurred via elderly exits (and lower youth entries) rather than substantial worker flows. This hints that the role of labor market frictions has been substantial on both demand and supply side and temporary unemployment was much rarer than permanent inactivity. It is important to note here, that Poland was a country with the highest unemployment rate among CEE transition economies, which hints that labor market frictions may have played a more important role than in other countries. This may also explain why - given this high unemployment - these are the smooth elderly exits rather than frictional worker flows that contributed so largely to changing employment structure.

Second, the role of frictions in job creation requires stronger focus in both academia and future policy. Namely, we show that even trend components tend to show strong positive correlations with the business cycle. This hints that vivid investment and net job creation are crucial for employment structure adjustment. This process is homogenous over the entire two decades under scrutiny.

Our study is burdened with some of the shortcomings in the earlier literature. First, we utilize data from one economy only. However, even two decades after the transition has started, obtaining consistent and coherent (quarterly) micro datasets remains a challenge. Macroeconomic indicators should not be used in this type of study, because, as we show, net flows may have very different dynamics from gross flows. Second, our data start in 1995 and it appears that some of the change in employment - in particular the decline of public sector could be stronger in early years. However, earlier data will remain unavailable, as they were simply not collected. On the other hand, it is not likely that earlier data would alter the 
cyclical properties of these time series. Rather, early years could reveal somewhat stronger relationship between some indicators, which in post 1995 data is puzzlingly low. 


\section{References}

Aghion, P. and Blanchard, O.J. 1994. On the speed of transition in Central Europe, NBER Macroeconomics Annual, Vol. 9, pp. 283-330.

Bilsen, V. and Konings, J. 1998. Job Creation, Job Destruction, and Growth of Newly Established, Privatized, and State-Owned Enterprises in Transition Economies: Survey Evidence from Bulgaria, Hungary, and Romania, Journal of Comparative Economics, Vol. 26, No. 3, pp.429-445.

Brown, J. D. and Earle, J.S. 2002. Gross job flows in Russian industry before and after reforms: Has destruction become more creative?, Journal of Comparative Economics, Vol. 30, No.1, pp.96-133.

Brown, J.D. and Earle, J.S. 2003. The reallocation of workers and jobs in Russian industry, Economics of Transition, Vol.11, No. 2, pp.221-252.

Brown, J. D. and Earle, J.S. 2006. Job reallocation and productivity growth in the Ukrainian transition, Comparative Economic Studies, Vol. 48, No.2, pp.229-251.

Caballero, R. J. and Hammour, M. L. 1996a. On the ills of adjustment, Journal of Development Economics, Vol.51, No.1, pp.161-192.

Caballero, R. J. and Hammour, M. L. 1996b. On the timing and efficiency of creative destruction, The Quarterly Journal of Economics, Vol.111, No.3, pp.805-852.

Caballero, R. J. and Hammour, M. L. 1998, Jobless growth: appropriability, factor substitution, and unemployment. In: Carnegie-Rochester Conference Series on Public Policy, Vol. 48, pp.51-94.

Caballero, R. J. and Hammour, M. L. 2000. Creative destruction and development: Institutions, crises, and restructuring, NBER WP 7849.

Davis, S.J. and Faberman, J. and Haltiwanger, J. 2005. The Flow Approach to Labor Markets: New Data Sources, Micro-Macro Links and the Recent Downturn, IZA Discussion Paper No. 1639

Davis, S.J. and Faberman, J. and Haltiwanger, J. 2011. Labor Market Flows in the Cross Section and over Time, NBER WP 17294.

Davis, S.J. and Haltiwanger, J. 2014. Labor Market Fluidity and Economic Performance. NBER WP 20479.

De Loecker, J., and Konings. J. 2006. Job Reallocation and Productivity Growth in a Postsocialist Economy: Evidence from Slovenian Manufacturing, European Journal of Political Economy, Vol. 22, No. 2, pp. 388-408. 
Diamond, P. and Blachard, O.J. 1992. The Flow Approach To Labor Markets. American Economic Review, Vol.82, No.2, pp.354-359.

Elsby, M.W. and Michaels, R. and Solon, G. 2007. The Ins and Outs of Cyclical Unemployment, NBER WP 12853.

Elsby, M.W. and Hobijn, B. and Sahin, A. 2008. Unemployment Dynamics in the OECD, NBER WP 14617.

Faggio, G. and Konings J. 2003. Job creation, job destruction and employment growth in transition countries in the 90s, Economic Systems, Vol. 27, No. 2, pp.129-154.

Gimpelson, V., and Kapeliushnikov, R., and Lukiyanova, A. 2010. Stuck between surplus and shortage: demand for skills in Russian industry, Labour, Vol. 24, No.3, pp.311-332.

Gomes, P. 2010. Labour Market Flows: Facts from the United Kingdom, IZA Dicsussion Paper No. 5327.

Haltiwanger, J. and Vodopivec, M. 2002. Gross worker and job flows in a transition economy: an analysis of Estonia, Labour Economics, Vol. 9 No. 5, pp.601-630.

Hodrick, R.J and Prescott, E. 1997. Postwar U.S. Business Cycles: An Empirical Investigation, Journal of Money, Credit and Banking, Vol. 29, pp.1-16.

Jaimovich, N., and Siu, H.E. 2012, The trend is the cycle: Job polarization and jobless recoveries, NBER WP No. 18334.

Konings, J., and Lehmann H., and Schaefer, M.E. 1996. Job creation and job destruction in a transition economy: Ownership, firm size, and gross job flows in Polish manufacturing 1988-91, Labour Economics, Vol. 3, No.3, pp.299-317.

Masso, J. and Heshmati A. 2004. The optimality and overuse of labour in Estonian manufacturing enterprises, Economics of Transition, Vol.12, No 4, pp.683-720.

Nagypal, E. 2008. Worker Reallocation over the Business Cycle: The Importance of Employer-to-Employer Transitions.

Petrongolo, B. and Pissaridies, C. 2008. The Ins and Outs of European Unemployment, American Economic Review, Vol. 98, No. 2, pp.256-262.

Ravn, M.O. and Uhlig, H. 2002. On Adjusting the Hodrick-Prescott Filter for the Frequency Observations, The Review of Economics and Statistics, Vol.84, pp.371-376.

Shimer R. 2007. Reassesing the Ins and Outs of Unemployment, NBER WP 13421.

Svejnar J., and Tyrowicz, J. and van der Velde, L. 2016. Effects Of Labor Reallocation On Productivity And Inequality - Insights From Studies On Transition, Journal of Economic Surveys, DOI: 10.1111/joes.12167. 